\title{
CITRAAN DALAM KUMPULAN PUISI AYAT-AYAT API KARYA SAPARDI DJOKO DAMONO
}

\author{
M. Aris ${ }^{1}$, Erlina Zahar ${ }^{2}$, Sujoko ${ }^{3}$ \\ Program Studi Pendidikan Bahasa dan Sastra Indonesia, \\ Fakultas Keguruan dan Ilmu Pendidikan, Universitas Batanghari, \\ Jambi
}

\author{
arism0957@gmail.com \\ erlina_zahar@yahoo.co.id \\ sujoko1987@yahoo.com
}

\begin{abstract}
The purpose of this research is to describe the imagery in the poetry collection Ayat-ayat Api by Sapardi Djoko Damono. This research is qualitative descriptive. The main data is taken from the written excerpt which consists of imagery in the poetry collection Ayat-ayat Api by Sapardi Djoko Damono. The data is collected by using library technique which focused on imagery analysis in the poetry collection Ayat-ayat Api by Sapardi Djoko Damono. The data is analyzed by using analysis and descriptive technique. Based on the result of the analysis, it can be concluded that there are sight imagery, hearing imagery, movement imagery in 15 poetry collection Ayat-ayat Api by Sapardi Djoko Damono. So it can be said that there are, 1) sight imagery consists of 10 expressions. 2) Hearing imagery consists of 10 expressions. 3) Movement imagery consists of 11 expressions. Thus, all of the expressions from that three imagery are 31 expressions from 15 poetry collection in Ayat-ayat Api by Sapardi Djoko Damono.
\end{abstract}

Keywords: Analysis, Imagery, Poetry Collection

\footnotetext{
${ }^{1}$ Mahasiswa Program Studi Pendidikan Bahasa dan Sastra Indonesia, Fakultas Keguruan dan Ilmu Pendidikan, Universitas Batanghari, Jambi

${ }^{2}$ Dosen Program Studi Pendidikan Bahasa dan Sastra Indonesia, Fakultas Keguruan dan Ilmu Pendidikan, Universitas Batanghari, Jambi

${ }^{3}$ Dosen Program Studi Pendidikan Bahasa dan Sastra Indonesia, Fakultas Keguruan dan Ilmu Pendidikan, Universitas Batanghari Jambi
} 


\section{PENDAHULUAN}

Karya sastra suatu seni yang indah dalam kehidupan. Karya sastra bisa menyentuh perasaan dan hati nurani manusia, karena di dalamnya berisikan tentang ungkapan jiwa, isi hati, dan pandangan penyair. Karya sastra terlahir dari hasil kombinasi antara gejolak batin dan imajinasi sastrawan yang kemudian dicampurkan dengan realita kehidupan. Itulah sebabnya karya sastra menjanjikan sebuah pengalaman batin baru yang nikmat serta dapat diambil manfaatnya dalam kehidupan sehari-hari, karena ia tidak hanya sebagai sarana penghibur tetapi juga penuh dengan makna dan mempunyai nilai bersifat mendidik.

Karya sastra juga bisa dikatakan sebagai potret kehidupan masyarakat. Karya sastra tercipta karena adanya pengalaman batin pengarang berupa peristiwa atau permasalahan dunia yang menarik sehingga muncul gagasan imajinasi yang dituangkan dalam bentuk tulisan dan karya sastra akan menyumbangkan tata nilai figur dan tatanan tuntutan masyarakat, hal ini merupakan ikatan timbal balik antara karya sastra dengan masyarakat. Karya sastra selalu menampilkan gambaran hidup dan kehidupan itu sendiri, yang merupakan kenyataan sosial.

Salah satu hasil dari karya sastra yang perkembangannya cukup pesat dan banyak digemari oleh pembaca adalah puisi. Hal ini bisa dibuktikan dengan hadirnya berbagai macam karya puisi dalam bentuk antologi. Selain itu, menurut pengamatan penulis setiap diadakannya perlombaan baik membaca maupun menulis puisi para peserta yang hadir cukup banyak. Kemudian fenomena yang bisa kita lihat sehari-hari bukti dari bentuk kebutuhan dan kecintaan masyarakat terhadap puisi adalah dengan banyaknya pengguna media sosial yang mengutarakan suasana hati atau menyampaikan pesan untuk seseorang melalui puisi. Puisi bisa kita artikan sebagai ungkapan perasaan dari penyair yang dirangkai menjadi suatu bentuk tulisan dan disusun ke dalam bait dengan kata yang sangat padat namun mengandung berjuta makna. Puisi juga dirangkai dengan kata yang indah yang tersusun dari pengalaman pribadi maupun pengalaman orang lain dalam kehidupan sehari-hari. Inilah yang menjadi alasan peneliti mengambil kajian puisi.

Kaitannya dengan puisi Sapardi Djoko Damono, berdasarkan sumber yang peneliti baca di media sosial (http://ensiklopedia.kemdikbud.go.id./sas tra/artikel/ Sapardi Djoko Damono) yang di akses pada 4 Desember 2017 bahwa Sapardi Djoko Damono terkenal sebagai penyair. Di samping itu, Sapardi dikenal sebagai dosen, pengamat sastra, kritikus sastra, dan pakar sastra.

Beberapa penghargaan dan hadiah sastra diterima Sapardi Djoko Damono atas prestasinya dalam menulis puisi. Tahun 1963 ia mendapat Hadiah Majalah Basis atas puisinya "Ballada Matinya Seorang Pemberontak"; tahun 1978 menerima penghargaan Cultural Award dari Pemerintah Australia; tahun 1983 memperoleh hadiah Anugerah Puisi-Puisi Putera II untuk bukunya Sihir Hujan dari Malaysia; tahun 1984 mendapat hadiah dari Dewan Kesenian Jakarta atas bukunya yang berjudul Perahu Kertas; tahun 1985 menerima Mataram Award; dan tahun 1986 ia menerima hadiah SEA Write Award (Hadiah Sastra Asean) dari Thailand. Sapardi juga mendapat Anugerah Seni dari Departemen Pendidikan dan Kebudayaan tahun 1990. Dalam tahun 1996 ia memperoleh Kalyana Kretya dari Menristek RI. Tahun 2003 Sapardi mendapat penghargaan The Achmad Bakrie Award for Literature dan tahun 2004 Sapardi memperoleh Khatulistiwa Award. Pada tahun 2012, Sapardi juga mendapat penghargaan dari Akademi Jakarta. 
Membaca puisi merupakan suatu proses komunikasi yang agak rumit. Ada komunikasi langsung antara pembaca dan puisi, tetapi pembaca belum tentu bisa berkomunikasi secara langsung dengan si penyair. Lewat puisinya itulah penyair 'berkomunikasi' dengan pembaca, tetapi karena puisi disusun dalam bahasa, bisa saja apa yang diniatkan penyair tidak sampai ke pembaca (Damono, 2016:33). Bila kita perhatikan memang tidak semua orang bisa memahami puisi sepenuhnya. Karena didalam puisi akan kita jumpai teks-teks yang memiliki medan makna yang sangat luas. Hanya sebagian orang yang memiliki intelektualitas tertentu saja yang bisa menerjemahkan maksud dari puisi tersebut.

Puisi banyak memanfaatkan kekuatan citraan untuk melukiskan sesuatu agar mudah diimajinasikan, dengan adanya citraan pembaca seolaholah dapat tergugah tanggapan inderanya. Dalam citraan akan menimbulkan suatu kesan dan pikiran yang dimunculkan dari kata, kelompok kata, atau kalimat di dalam puisi. Pada penelitian ini, penulis melakukan penelitian agar dapat menggali unsur pembangun, seperti unsur citraan dimana di dalam karya sastra citraan dapat digunakan untuk mengelompokan dan menilai karya sastra.

Berdasarkan uraian di atas, beberapa alasan penulis melakukan penelitian ini, yaitu:

1. Puisi banyak digemari oleh pembaca, terbukti dengan banyaknya karya puisi dalam bentuk antologi.

2. Kumpulan puisi Ayat-Ayat Api karya Sapardi Djoko Damono merupakan buku kumpulan puisi yang baru diterbitkan pada tahun 2017.

3. Puisi-puisi Sapardi Djoko Damono memiliki keistimewaan dan juga tantangan bagi pembaca, karena puisi tersebut kaya akan citraan. Maka menganalisis citraan dari puisi ini akan mempermudah pembaca untuk mengetahui makna puisi.

Berdasarkan beberapa alasan di atas, peneliti tertarik untuk meniliti tentang citraan yang mungkin dapat memberikan manfaat bagi pembaca. Maka dari itu penelitian ini dituangkan dalam bentuk skripsi dengan judul, "Analisis Citraan dalam Kumpulan Puisi Ayat-Ayat Api Karya Sapardi Djoko Damono".

Berdasarkan latar belakang di atas masalah yang teridentifikasi adalah citraan. Menurut Pradopo, (2014:82) citraan/imaji terbagi menjadi tujuh yakni, citraan penglihatan, citraan pendengaran, citraan perabaan, citraan penciuman, citraan pencecapan, citraan pemikiran dan citraan gerak. Sedangkan objek kajian yang akan di teliti pada penelitian ini adalah kumpulan puisi Ayat-ayat Api karya Sapardi Djoko Damono yang berjumlah 54 puisi.

Berdasarkan uraian yang terdapat pada batasan masalah di atas, dengan keterbatasan waktu dan kemampuan maka penulis hanya fokus pada tiga dari tujuh citraan yang ada yaitu, citraan penglihatan, citraan pendengeran, dan citraan gerak. Selain itu penulis hanya menganalisis 15 puisi dari 54 puisi yang terdapat dalam kumpulan puisi Ayat-ayat Api karya Sapardi Djoko Damono. Penulis mengambil 15 puisi ini dengan cara acak. Puisi yang penulis pilih adalah sebagai berikut: 1) Ruang Ini, 2) Catatan Masa Kecil, 3) Di Depan Pintu, 4) Salam Matahariku, 5) Bunga Randu Alam, 6) Iklan, 7) Kelereng, 8) Adam dan Hawa, 9) Ruang Tunggu, 10) Dongeng Kucing, 11) Pada Suatu Magrib, 12)Jakarta, Juli 1996, 13) Sebelum Fajar, 14) Pokok Kayu, 15) Ayat-ayat Api.

Berdasarkan fokus penelitian yang telah dijelaskan maka pertanyaan penelitian ini adalah sebagai berikut: 
1. Bagaimanakah citraan penglihatan dalam kumpulan puisi Ayat-ayat Api karya Sapardi Djoko Damono?

2. Bagaimanakah citraan pendengaran dalam kumpulan puisi Ayat-ayat Api karya Sapardi Djoko Damono?

3. Bagaimanakah citraan gerak dalam kumpulan puisi Ayat-ayat Api karya Sapardi Djoko Damono?

Tujuan penelitian secara umum untuk meningkatkan daya nalar untuk mencari jawaban permasalahan itu melalui penelitian. Adapun tujuan penelitian ini adalah sebagai berikut:

1. Untuk mendeskripsikan citraan penglihatan dalam kumpulan puisi Ayat-ayat Api karya Sapardi Djoko Damono.

2. Untuk mendeskripsikan citraan pendengeran dalam kumpulan puisi Ayat-ayat Api karya Sapardi Djoko Damono.

3. Untuk mendeskripsikan citraan gerak dalam kumpulan puisi Ayat-ayat Api karya Sapardi Djoko Damono.

\section{METODE PENELITIAN}

Adapun jenis penelitian ini adalah deskriftif kualitatif. "Metode deskriptif dapat diartikan sebagai prosedur pemecahan masalah yang diselidiki dengan menggambarkan atau melukiskan keadaan subjek dan objek penelitian (novel, drama, cerita pendek, puisi) pada saat sekarang berdasarkan fakta-fakta yang tampak atau sebagaimana adanya”

Berdasarkan paparan di atas dapat digambarkan bahwa penelitian ini menggunakan jenis penelitian kualitatif dengan metode deskriptif. Penelitian kualitatif dengan metode deskriptif adalah penelitian yang menggambarkan dan mengungkapkan sesuatu melalui kata-kata baik lisan maupun tulisan berdasarkan fakta atau fenomena tentang apa yang dialami oleh subjek penelitian. Jenis metode ini digunakan untuk mendeskripsikan data-data tentang aspek citraan dalam kumpulan puisi Ayat-ayat Api karya Sapardi Djoko Damono. Data yang terurai dalam bentuk kata-kata.

Teknik pengumpulan data mempunyai peranan yang sangat penting dalam sebuah penelitian. "Teknik pengumpulan data merupakan langkah paling strategis dalam penelitian, karena tujuan utama dari penelitian adalah mendapatkan data” (Sugiyono, 2013:224). Jadi, tanpa teknik pengumpulan data, maka penulis tidak akan mendapatkan data yang memenuhi standar data yang ditetapkan. Teknik pengumpulan data dalam penelitian ini menggunakan teknik studi pustaka dan analisis citraan penglihatan, pendengaran, dan gerak yang terdapat dalam kumpulan puisi Ayat-ayat Api karya Sapardi Djoko Damono.

Dalam hal ini, teknik pengumpulan data pada penelitian ini difokuskan menganalisis citraan penglihatan, pendengaran, dan gerak dalam kumpulan puisi Ayat-ayat Api karya Sapardi Djoko Damono. Langkahlangkahnya sebagai berikut:

1. Peneliti membaca keseluruhan puisi yang akan diteliti secara cermat dan berulang-ulang. Hal ini dilakukan untuk mencermati jenis citraan apa saja yang terdapat dalam kumpulan puisi Ayat-ayat Api karya Sapardi Djoko Damono.

2. Peneliti menandai dan mencatat bagian kata-kata atau kalimat-kalimat yang berhubungan dengan aspek citraan puisi.

3. Peneliti mencatat data yang berhubungan dengan aspek citraan puisi.

4. Peneliti mengumpulkan data sesuai dengan aspek citraan puisi.

5. Setelah data terkumpul, kemudian dikelimpokkan data sesuai dengan aspek-aspek yang akan diteliti yaitu: Citraan penglihatan, citraan pendengaran, dan citraan gerak yang 
terdapat dalam kumpulan puisi Ayatayat Api karya Sapardi Djoko Damono.

6. Peneliti mengklasifikasikan data sesuai dengan aspek citraan puisi.

Analisis data dilakukan setelah data terkumpul dengan menggunakan analisis data melalui tahapan sebagai berikut:

1. Data yang sudah diklafikasikan, dimasukkan ke dalam tabel tabulasi data.

2. Menganalisis data yang sesuai dengan aspek penelitian yang terkandung dalam isi teks puisi.

3. Data yang sudah dianalisis, kemudian dideskripsikan sesuai dengan aspekaspek penelitian yang terkandung dalam isi teks puisi.

4. Setelah data dianalisis dan dideskripsikan, langkah selanjutnya penulis tidak langsung menyimpulkan. Untuk memperoleh hasil yang akurat penulis melakukan keabsahan data melalui triangulasi data.

5. Data yang sudah dianalisis dan dideskripsikan kemudian disimpulkan

\section{HASIL DAN PEMBAHASAN}

Setelah menganalisis citraan penglihatan, citraan pendengaran, dan citraan gerak terhadap 15 puisi dalam kumpulan puisi Ayat-ayat Api karya Sapardi Djoko Damono maka dapat penulis deskripsikan bahwa, 1) terdapat citraan penglihatan di dalam 15 puisi Ayat-ayat Api karya Sapardi Djoko Damono, ke 15 puisi itu menggambarkan bahwa apa yang dilihat oleh penyair seolah-olah dapat juga terlihat oleh pembaca puisi, citraan penglihatan berjumlah 10 kutipan. 2) terdapat citraan pendengaran di dalam 15 puisi Ayat-ayat Api karya Sapardi Djoko damono, dalam puisi tersebut menggambarkan bahwa suara yang di dengar oleh penyair seolah-olah juga dapat di dengar oleh pembaca puisi, citraan pendengaran berjumlah 10 kutipan. 3) terdapat citraan gerak di dalam 15 puisi Ayat-ayat Api karya Sapardi Djoko Damono, dalam puisi tersebut menggambarkan bahwa hal-hal yang dirasakan bergerak oleh penyair seolah-olah juga dirasakan langsung oleh pembaca puisi, citraan gerak berjumlah 11 kutipan. Sehingga seluruh kutipan dari ketiga citraan itu terdapat 31 kutipan dari 15 puisi Ayat-ayat Api karya Sapardi Djoko Damono. Selanjutnya untuk lebih jelasnya dideskripsikan kutipan-kutipan pada bagian berikut ini.

\section{a. Citraan Penglihatan}

Citraan penglihatan dalam kumpulan puisi Ayat-ayat Api karya Sapardi Djoko Damono diantaranya terdapat pada kutipan sebagai berikut:

1) "seberkas bunga plastik di atas meja, asbak yang penuh, dan sebuah buku yang terbuka pada halaman pertama” (Ruang ini, hlm. 3)

2) "Cahaya yang tiba-tiba pasang mengajaknya pergi” (di Depan Pintu, hlm. 6)

3) "belum ada seorang pun di ruang tunggu beberapa bangku panjang yang kosong tak juga mengundangnya duduk” (Ruang Tunggu, hlm. 39)

4) "Bunga randu alas itu telah merekah” (Bunga Randu Alas, hlm. 27)

5) "Pohon randu alas itu menjulang di kuburan samping rumah kami” (Bunga Randu Alas, hlm. 27)

\section{b. Citraan Pendengaran}

Citraan pendengaran dalam kumpulan puisi Ayat-ayat Api karya Sapardi Djoko Damono diantaranya terdapat pada kutipan sebagai berikut:

1) "ketika ibunya sakit keras dan ayahnya tidak ada di rumah dan di halaman terdengar langkah-langkah 
bakiak almarhum neneknya” (Catatan Masa Kecil, hlm. 4)

2) "kenapa selalu terbayang bara sisa ketika kutatap bunga itu,” kata angin yang diam-diam terlanjur mencintainya” (Bunga Randu Alas, hlm. 27)

3) “setiap kemarau bunga-bunganya yang merah suka melengking, bahkan sampai larut malam” (Bunga Randu Alas, hlm. 27)

4) "dan istrinya suka tidak paham jika ia mendadak terbahak-bahak ketika menyaksikan iklan tentang kepedulian sosial itu” (Iklan, hlm. 30)

5) "namun mendadak seperti didengarnya suara yang sangat lirih dari kamar periksa ada yang sedang menyanyikan beberapa ayat kitab suci” (Ruang Tunggu, hlm. 39)

\section{c. Citraan Gerak}

Citraan gerak dalam kumpulan puisi Ayat-ayat Api karya Sapardi Djoko Damono dinataranya tedapat pada kutipan sebagai berikut:

1) "kau cari catatan kaki itu, sia-sia" (Ruang Ini, hlm. 3)

2) "di depan pintu bayang-bayang bulan terdiam di rumput” (Di Depan Pintu, hlm. 6)

3) "Cahaya yang tiba-tiba pasang mengajaknya pergi” (Di Depan Pintu, hlm. 6)

4) "salamku matahari! Yang membagibagikan warna di laut, di padangpadang yang dilupakan" (Salamku Matahari, hlm. 16)

5) "kepala bergoyang-goyang dan matanya berbinar-binar” (Iklan, hlm. 30)

Berdasarkan hasil analisi data yang telah dilakukan, maka dapat dijelaskan sebagai berikut.

\section{a. Citraan Penglihatan dalam Kumpulan Puisi Ayat-ayat Api karya Sapardi Djoko Damono}

Citraan penglihatan adalah citraan yang timbul oleh penglihatan. Citraan ini memberikan rangsangan kepada indera penglihatan yaitu mata. Dalam kumpulan puisi Ayat-ayat Api karya Sapardi Djoko Damono citraan penglihatan dapat dilihat dalam kutipan berikut:

1) "seberkas bunga plastik di atas meja, asbak yang penuh, dan sebuah buku yang terbuka pada halaman pertama” (Ruang ini, hlm. 3)

Pada penggalan bait puisi tersebut terdapat kutipan yang mana pengarang menggunakan diksi yang tepat untuk merangsang daya bayang pembaca sehingga pembaca digiring melihat bunga plastik di atas meja dan melihat asbak yang penuh serta sebuah buku yang terbuka pada halaman pertama. Pilihan kata yang digunakan pengarang bertujuan untuk menceritakan apa yang dilihatnya sehingga pembaca juga dapat melihat hal tersebut.

2) "Cahaya yang tiba-tiba pasang mengajaknya pergi” (Di Depan Pintu, hlm. 6)

Pada penggalan bait puisi tersebut terdapat citraan penglihatan pada kata cahaya yang tiba-tiba pasang. Penyair ingin menggugah daya bayang pembaca bahwa seolah-olah melihat matahari sedang terbit dan memancarkan cahayanya.

3) "belum ada seorang pun di ruang tunggu beberapa bangku panjang yang kosong tak juga mengundangnya duduk” (Ruang Tunggu, hlm. 39)

Pada kutipan puisi tersebut pengarang ingin menyampaikan bahawa ia benar-benar melihat beberapa bangku yang kosong yang terdapat di ruang tunggu sebuah rumah sakit. Diksi yang digunakan oleng pengarang juga dapat 
merangsang daya bayang pembaca bahwa ia benar-benar melihat beberapa bangku kososng.

4) "Bunga randu alas itu telah merekah" (Bunga Randu Alas, hlm. 27)

Pada bait puisi di atas terdapat citraan penglihatan pada kalimat bunga randu alas itu telah merekah. Penyair ingin mengajak pembaca untuk membyangkan bahwa ia benar-benar melihat sebuah bunga yang telah merekah atau mekar.

5) "Pohon randu alas itu menjulang di kuburan samping rumah kami” (Bunga Randu Alas, hlm. 27)

Kalimat pada bait puisi di atas terdapat citraan penglihatan. Karena penyair ingin merangsang pembaca untuk membayangkan bahwa di samping sebuah rumah terdapat sebatang pohon yang sangat menjulang dan pembaca seakan-akan bisa melihat itu dengan jelas.

\section{b. Citraan Pendengaran dalam Kumpulan Puisi Ayat-ayat Api karya Sapardi Djoko Damono}

Citraan pendengaran adalah citraan yang menghasilkan dengan menyebutkan atau menguraikan bunyi suara. Citraan ini memberikan rangsangan kepada indera pendengaran, sehingga kata-kata itu seolah-olah mengeluarkan bunyi, dan pembaca dapat mengungkapkan bunyi. Dalam kumpulan puisi Ayat-ayat Api karya Sapardi Djoko Damono citraan pendengaran dapat dilihat dalam kutipan berikut:

1) "ketika ibunya sakit keras dan ayahnya tidak ada di rumah dan di halaman terdengar langkahlangkah bakiak almarhum neneknya” (Catatan Masa Kecil, hlm. 4)

Kutipan di atas mampu mengunggah indera pendengaran pembaca untuk mendengarkan bagaimana suara langkah-langkah kaki di halaman rumah. Penyair ingin menceritakan seorang anak yang berada di dalam rumah dan mendengarkan suara langkah-langkah kaki di halaman rumahnya.

2) "kenapa selalu terbayang bara sisa ketika kutatap bunga itu,” kata angin yang diam-diam terlanjur mencintainya” (Bunga Randu Alas, hlm. 27)

Dari penggalan bait puisi tersebut, penyair menggambarkan citraan pendengaran dengan kutipan kata angin. Penyair ingin menyampaikan dan mengajak pembaca untuk membayangkan bahwa angin mampu berkata dan mengeluarkan suara.

3) "setiap kemarau bunga-bunganya yang merah suka melengking, bahkan sampai larut malam” (Bunga Randu Alas, hlm. 27)

Kutipan suka melengking pada bait puisi di atas merupakan citraan pendengaran. Sang penyair ingin mengajak pembaca untuk membayangkan bahwa ia dan pembaca benar-benar mendengar seolah suara lengkingan itu berasal dari bunga-bunga.

4) “dan istrinya suka tidak paham jika ia mendadak terbahakbahak ketika menyaksikan iklan tentang kepedulian sosial itu" (Iklan, hlm. 30)

Dari penggalan bait puisi di atas , penyair menggambarkan citraan pendengaran dengan kata terbahakbahak. Penyair ingin mengajak pembaca untuk membayangkan bahwa terdengar suara tawa dari seseorang dengan keras dan berisik.

5) "namun mendadak seperti didengarnya suara yang sangat lirih dari kamar periksa ada yang sedang menyanyikan beberapa ayat kitab suci” (Ruang Tunggu, hlm. 39) 
Penggalan bait puisi di atas dengan diksinya penyair mampu menggugah indera pendengaran pembaca untuk mendengarkan suara seseorang yang sedang malantunkan beberapa ayat kitab suci dengan suara yang berat dan lirih seperti orang yang sedang sakit.

\section{c. Citraan Gerak dalam Kumpulan Puisi Ayat-ayat Api karya Sapardi Djoko Damono}

Citraan gerak adalah citraan yang menggambarkan sesuatu yang sesungguhnya tidak bisa bergerak tapi dilukiskan sebagai dapat bergerak ataupun gambaran gerak pada umumnya. Citraan gerak juga sangat produktif dalam karya sastra karena mampu membangkitkan imaji/daya bayang pembaca. Dalam kumpulan puisi Ayatayat Api karya Sapardi Djoko Damono citraan gerak dapat dilihat dalam kutipan berikut:

1) "kau cari catatan kaki itu, siasia” (Ruang Ini, hlm. 3)

Dalam penggalan bait puisi tersebut, penyair menggambarkan citraan gerak pada kalimat kau cari catatan kaki itu. Penyair berusaha untuk mengantarkan pembaca agar membayangkan ada aktifitas gerak dari seseorang yang berusaha membolakbalikkan sebuah buku guna mencari catatan kaki pada buku tersebut.

2) "di depan pintu bayang-bayang bulan terdiam di rumput” (Di Depan Pintu, hlm. 6)

Pada penggalan bait puisi di atas terdapat citraan gerak pada kalimat bayang-bayang bulan terdiam di rumput. Penyair ingin menggiring daya bayang pembaca bahwa seolah-olah bayangbayang bulan itu mampu bergerak kesana kemari namun kali ini ia hanya terdiam di rumput.

3) "Cahaya yang tiba-tiba pasang mengajaknya pergi” (Di Depan Pintu, hlm. 6)
Pada penggalan bait puisi di atas terdapat citraan gerak pada kalimat cahaya yang tiba-tiba pasang mengajaknya pergi. Penyair ingin menggugah daya bayang pembaca untuk membayangkan bahwa cahaya tersebut mampu bergerak layaknya manusia dengan mengajak bayang-bayang bulan untuk pergi.

4) "salamku matahari! Yang membagi-bagikan warna di laut, di padang-padang yang dilupakan” (Salamku Matahari, hlm. 16)

Dari penggalan bait puisi di atas, penyair menggambarkan citraan gerak pada kata yang membagi-bagikan. Penyair ingin menggugah daya baya pembaca bahwa seolah-olah matahari mampu melakukan aktifitas gerak layaknya manusia dengan membagibagikan cahayanya.

5) "kepala bergoyang-goyang dan matanya berbinar-binar” (Iklan, hlm. 30)

Dari penggalan bait puisi tersebut, penyair menggambarkan citraan gerak dengan kata kepala bergoyang-goyang. Kepala bergoyang-goyang adalah salah satu aktifitas gerak yang mana seseorang mengoyang-goyangkan kepala baik keatas kebawah ataupun kesamping. Penyair ingin mempengaruhi daya bayang pembaca sehingga pembaca terbawa suasana kata pada puisi tersebut sambil menggoyang-goyangkan kepalanya sendiri.

\section{SIMPULAN}

Berdasarkan pemaparan hasil penelitian dan pembahasan, dapat disimpulkan bahwa terdapat citraan penglihatan, citraan pendengaran, dan citraan gerak terhadap 15 puisi dalam kumpulan puisi Ayat-ayat Api karya Sapardi Djoko Damono maka dapat penulis deskripsikan sebagai berikut, 1) terdapat citraan penglihatan di dalam 15 puisi Ayat-ayat Api karya Sapardi Djoko 
Damono, ke 15 puisi itu menggambarkan bahwa apa yang dilihat oleh penyair seolah-olah dapat juga terlihat oleh pembaca puisi, citraan penglihatan berjumlah 10 kutipan. 2) terdapat citraan pendengaran di dalam 15 puisi Ayat-ayat Api karya Sapardi Djoko damono, dalam puisi tersebut menggambarkan bahwa suara yang di dengar oleh penyair seolah-olah juga dapat di dengar oleh pembaca puisi, citraan pendengaran berjumlah 10 kutipan 3). terdapat citraan gerak di dalam 15 puisi Ayat-ayat Api karya Sapardi Djoko Damono, dalam puisi tersebut menggambarkan bahwa hal-hal yang dirasakan bergerak oleh penyair seolah-olah juga dirasakan langsung oleh pembaca puisi, citraan gerak berjumlah 11 kutipan. Sehingga seluruh kutipan dari ketiga citraan itu terdapat 31 kutipan dari 15 puisi Ayat-ayat Api karya Sapardi Djoko Damono.

Dalam puisi ini penyair menampilkan kata-kata yang indah, menarik dan mampu menggugah imajinasi pembaca khususnya pada 3 citraan yang peneliti analisis . penyair banyak menggunakan daya komunikasi melalui daya bayang yaitu penglihatan, pendengaran dan gerak. Jadi, penikmat puisi seolah-olah bisa merasakan secara langsung peristiwa yang dialami oleh penyair.

\section{DAFTAR PUSTAKA}

Damono, Sapardi Djoko. (2017). Ayatayat Api. Jakarta: PT Gramedia Pustaka Utama.

Moleong, Lexy J. (2014). Metodologi Penelitian Kualitatif. Bandung: PT Remaja Rosdakarya.

Pradopo, Rachmad Djoko. (2014). Pengkajian Puisi. Yogyakarta: Gajahmada University Press.

Siswantoro, (2010). Metode Penelitian Sastra. Yogyakarta. Pustaka Pelajar.
Sugiyono. (2013). Metode Penelitian Kuantitatif, Kualitatif. Bandung: Alfabeta.

(http://ensiklopedia.kemdikbud.go.id./sas tra/artikel/Sapardi Djoko Damono) (di akses pada 4 Desember 2018). 